\title{
Desain Aquatic Weed and Trash Skimmer Boat dengan Sistem Penggerak Paddle Wheel di Sungai Kalimas Surabaya
}

\author{
Arief Ega Pratama dan Hesty Anita Kurniawati \\ Departemen Teknik Perkapalan, Fakultas Teknologi Kelautan, Institut Teknologi Sepuluh Nopember (ITS) \\ e-mail: tita@na.its.ac.id
}

\begin{abstract}
Abstrak-Surabaya sebagai kota terbesar kedua di Indonesia memiliki masalah yang cukup serius yaitu banjir setiap tahun yang disebabkan timbunan sampah dan tumbuhan air khususnya di sungai-sungai. Jurnal ini mempunyai tujuan untuk melakukan analisis secara teknis mengenai desain kapal yang cocok untuk karakteristik Sungai Kalimas itu sendiri. Dipilih lambung katamaran dengan conveyor dibagian haluan, buritan dan di ruang muat serta dilengkapi alat pemotong dibagian haluan dikarenakan katamaran memiliki geladak yang luas sehingga dapat mengangkut muatan lebih banyak. Selain itu kapal pembersih ini dirancang dengan sistem penggerak paddle wheel agar dapat bermanuver pada perairan yang cukup dangkal tanpa harus takut terhambat sampah maupun tumbuhan air sehingga cocok untuk kondisi Sungai Kalimas Surabaya. Proses desain kapal dilakukan dengan menentukan payload untuk mendapatkan ukuran utama kapal awal kemudian dilakukan proses optimasi dengan metode 256. Perhitungan teknis menggunakan rules untuk kapal katamaran dengan $\mathbf{L}<50 \mathrm{~m}$. Hasil perhitungan teknis diperoleh ukuran utama Kapal Aquatic Weed and Trash Skimmer sebesar $L_{o a}=9.6 \mathrm{~m}, L_{w l}=9,2 \mathrm{~m}, B=6 \mathrm{~m}, B_{0 a}=8 \mathrm{~m}, B_{1}=$ $1.3 \mathrm{~m} \mathrm{~T}=0.7 \mathrm{~m}, \mathrm{H}=1.7 \mathrm{~m}, \mathrm{C}_{\mathrm{b}}=0,5$ dan $\mathrm{V}_{\mathrm{S}}=4$ knots. Selanjutnya dari ukuran utama yang diperoleh dibuat Gambar Rencana Garis, Gambar Rencana Umum, dan Model 3D serta melakukan analisis biaya pembangunan.
\end{abstract}

Kata Kunci-Aquatic Weed, Catamaran, Conveyor, Trash Skimmer, Paddle wheel, Sungai Kalimas Surabaya.

\section{PENDAHULUAN}

$\mathrm{S}$ URABAYA merupakan kota terbesar kedua setelah Ibu Kota Jakarta dengan luas sekitar $350,54 \mathrm{~km}$ persegi dan jumlah penduduk 3.016.653 jiwa [1]. Jumlah penduduk yang tinggi menyebabkan tingkat produktifitas sampah yang tinggi pula setiap harinya. Timbunan sampah tersebut dapat terjadi di darat maupun di perairan. Selain timbunan sampah yang ada di perairan, tumbuhan air seperti eceng gondok, alga, rerumputan air, dll juga dapat mengganggu kondisi perairan. Tumbuhan ini nantinya akan menghambat laju sampah yang hanyut sehingga timbunan sampah ini akan berhenti pada suatu titik. Karena setiap hari sampah yang hanyut tetap ada dan relatif bertambah, sampah tersebut lama kelamaan akan menutupi badan sungai. Badan sungai yang tertutupi oleh sampah mengakibatkan kapasitas air yang dapat ditampung oleh sungai akan berkurang, selain itu tumbuhan air tersebut juga dapat menyebabkan pendangkalan sungai.

Sehubungan latar belakang tersebut, permasalahan yang akan dikaji dalam Jurnal ini adalah bagaimana desain kapal kerja yang sesuai untuk membersihkan sampah dan tanaman air di Sungai Kalimas Surabaya dan sistem operasional kapal kerja yang dapat dioperasionalkan secara optimal dan efisien untuk Sungai Kalimas Surabaya.

Adapun tujuan dari Jurnal ini adalah untuk mendapatkan ukuran utama yang nantinya sebagai acuan pembuatan Linesplan dan General Arrangement serta Model 3D yang efektif dan efisien dalam pemersihan sampah dan tumbuhan air di Sungai Kalimas Surabaya. Kemudian untuk menetukan sistem operasional loading-offloading yang sesuai dengan karakteristik sampah yang ada. Serta untuk mendapatkan desain kapal kerja yang ekonomis dengan biaya pembangunan yang terjangkau bagi pemerintah Kota Surabaya.

\section{TINJAUAN PUSTAKA}

\section{A. Trash Skimmer}

Trash Skimmer Boat merupakan kapal kerja dengan lambung katamaran dan dilengkapi conveyor belt yang dapat dinaikkan dan diturunkan sesuai kebutuhan. Conveyor belt tersebut mempunyai fungsi untuk mengumpulkan sampah yang mengapung di permukaan sungai dan bak penampung itu sendiri berfungsi untuk menampung sampah yang telah dikumpulkan. Pengumpulan sampah dilakukan melalui sisi haluan kapal. Pada sisi haluan kapal yang berfungsi sebagai pintu masuknya sampah terdapat lengan yang dapat digerakkan sesuai keinginan. Lengan tersebut digerakan dengan sistem hidrolik [2].

\section{B. Katamaran}

Katamaran merupakan kapal yang mempunyai dua lambung atau badan yang dihubungkan oleh geladak atau bridging platform ditengahnya. Keuntungan kapal katamaran dibandingkan dengan monohull adalah dengan tenaga dorong yang sama kecepatan yang dihasilkan lebih besar, geladak kapal lebih luas, memiliki stabilitas lebih baik [3].

\section{Paddle Wheel}

Paddle wheel adalah sebuah bentuk dari kincir air dimana terdapat sejumlah dayung pada sepanjang pinggiran roda. Pemanfaatan paddle wheel antara lain sebagai pompa daya rendah (very-low water pumping), sebagai propulsi pada perahu atau kapal dan juga sebagai aerator. Paddle wheel pada kapal sangat tepat digunakan pada perairan dangkal (sallow water) karena menggunakan prinsip kerja kincir air yaitu tidak seluruh blades atau dayungnya tercelup air, tetapi hanya sebagian dari blades saja yang tercelup air [4]. 


\section{Sungai Kalimas Surabaya}

Surabaya merupakan salah satu kota terbesar kedua setelah Ibu Kota Jakarta dengan luas sekitar 350,54 km persegi dan jumlah penduduk 3.016.653 jiwa. Menjadi Ibu Kota dari Provinsi Jawa Timur, Surabaya merupakan pusat sentral industri yang memiliki peran penting dalam kemajuan wilayah khususnya Jawa Timur. Sungai utama yang berada di Kota Surabaya berasal dari Sungai Brantas yang mengalir melalui Kota Mojekerto. Di kota ini Sungai Brantas terbagi menjadi dua, yakni Sungai Porong dan Sungai Surabaya yang dimensinya lebih kecil. Di Wonokromo, Sungai Surabaya terpecah menjadi dua anak sungai, yaitu Sungai Kalimas dan Sungai Wonokromo. Sungai Kalimas mengalir ke arah pantai utara melewati tengah kota, sedangkan Sungai Wonokromo ke arah pantai timur dan bermuara di selat Madura [1].

\section{E. Segmentasi}

Segmentasi dilakukan dengan cara melihat semua batasanbatasan fisik yang ada di sepanjang Sungai Kalimas Surabaya. Sungai Kalimas mengalir sepanjang 15 kilometer berawal dari pintu air Ngagel dan bermuara di Pelabuhan Tanjung Perak Surabaya. Pada Gambar 1 di sepanjang Sungai Kalimas terdapat dua pintu air yaitu di daerah Ngagel dan di daerah Kayoon. Selain itu ada 14 jembatan yang melintas di atas Sungai Kalimas. Jembatan ini memiliki clearance height ratarata 4 meter dari permukaan air.

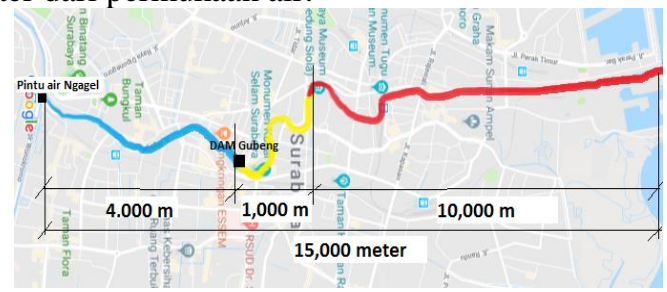

Gambar 1. Karakteristik Sungai Kalimas.

\section{F. Zoning}

Zoning dilakukan dengan cara melakukan survei lapangan secara langsung untuk melihat kondisi banyaknya timbunan sampah dan tumbuhan air yang terdapat di Sungai Kalimas. Setelah dilakukan pengamatan, kondisi sungai di daerah Monkasel ialah yang paling bersih, karena di daerah tersebut sudah dibangun tempat rekreasi yaitu taman ekspresi dan taman prestasi. Sedangkan daerah yang masih kotor terdapat mulai dari daerah Pasar Keputran sampai daerah Ngagel.

\section{G. Pemilihan Daerah Operasional}

Pemilihan daerah operasional Aquatic Weed and Trash Skimmer Boat ini dilakukan dengan cara melihat hasil dari segmentasi yang telah dilakukan yaitu berdasarkan batasanbatasan fisik yang ada di sekitar Sungai Kalimas Surabaya. Jika dilihat dari segi segmentasi, terdapat batasan fisik berupa pintu air DAM Gubeng di daerah Kayoon dan dilihat dari segi zoning daerah Jl. Achmad Jais sampai daerah Monkasel merupakan taman wisata yang sudah bersih karena di daerah tersebut sudah dibangun tempat rekreasi yaitu taman ekspresi dan taman prestasi, maka daerah tersebut tidak dipilih menjadi daerah operasional. Sehingga telah ditentukan daerah operasional yang dipilih yaitu mulai dari setelah Pintu Air
Ngagel lalu ke utara sampai dengan DAM Gubeng dengan jarak rute sekitar 4 kilometer seperti pada Gambar II.2.

\section{H. Sistem Operasional Loading-Offloading}

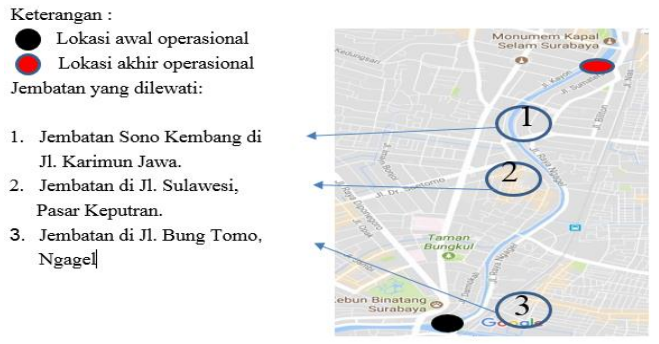

Gambar 2. Daerah operasional yang direncanakan.

Aquatic Weed and Trash Skimmer boat merupakan kapal yang dilengkapi conveyor belt yang saling berhubungan dari mulai haluan sampai buritan kapal serta dapat dinaikkan dan diturunkan sesuai kebutuhan menggunakan lengan hidrolik. Conveyor belt terdiri dari loading conveyor yang berada di bagian haluan kapal yang fungsinya untuk mengangkut sampah dan tumbuhan air yang berada di permukaan sungai, storage conveyor yang berada di geladak kapal berfungi sebagai tempat penyimpanan sementara sampah dan tumbuhan air yang sudah diangkut, sedangkan offloading conveyor terletak pada bagian buritan kapal dan berfungsi sebagai alat pembuangan muatan dari kapal menuju tempat pembuangan akhir [5]. Diujung loading conveyor nantinya akan dipasangi alat pemotong atau cutter yang fungsinya untuk memotong tumbuhan air seperti eceng gondok, kangkung air, ganggang air, dll.

\section{Penentuan Pola Operasional}

Dengan kecepatan 4 knot, kapal dapat melaju lurus dengan waktu 1 jam pada daerah operasional sehingga waktu operasional kapal ditentukan sesuai dengan standar kerja harian yaitu 8 jam perhari, yang terdiri dari 5 jam adalah waktu proses kapal melakukan skimming, dan 1.5 jam adalah waktu untuk offloading muatan dan sisanya untuk mempersiapkan alat. Operasional kapal akan dimulai dari jam 08.00 dan berakhir 16.00 tiap hari operasinya.

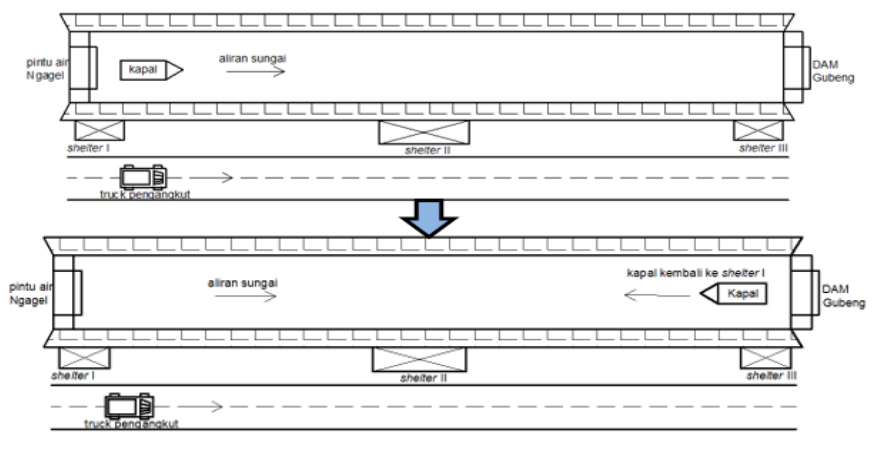

Gambar 3. Ilustrasi Operasional yang direncanakan.

Pada Gambar 3 menjelaskan tentang pola operasional kapal saat melakukan proses skimming dari shelter I menuju shelter II ditentukan kapal melaju dengan kecepatan 1 knot, setelah sampai di shelter II, kapal melakukan proses bongkar muatan. 
Kemudian kapal melanjutkan proses skimming menuju ke shelter III dengan kecepatan 1 knot. Setelah sampai di shelter III kapal melakukan bongkar muatan dan crew beristirahat. Setelah dari shelter III, kapal berbalik arah menuju ke shelter I dengan kecepatan 3 knot untuk melakukan proses skimming sampah-sampah yang kemungkin masih tertinggal, dan di shelter I kapal melakukan bongkar muatan lagi yang nantinya akan diangkut oleh truk.

\section{METODOLOGI PENELITIAN}

\section{A. Umum}

Metodologi dapat berupa suatu rumusan matematika, landasan berfikir, dan ketetapan umum. Metodologi tersebut mencakup semua pustaka yang berhubungan dengan penyelesaian Jurnal.

\section{B. Pencarian Data}

Untuk menghasilkan sebuah desain yang optimum, penulis melakukan penelitian dengan metode sistematis yang diawali dengan studi literatur, mengumpulkan data setelah itu melakukan identifikasi permasalahan untuk dicarikan solusi yang tepat. Kemudian berkaitan dengan desain kapal, penulis menentukan ukuran utama awal berdasarkan kapasitas ruang muat, yang kemudian ukuran utama awal ini akan dioptimasi menggunakan metode 256 .

\section{Pengolahan Data}

Setelah semua data yang dibutuhkan sudah didapatkan, selanjutnya adalah mengolah data tersebut untuk menghasilkan desain yang memenuhi syarat permintaan pemilik kapal atau sesuai dengan tujuan dibangunnya kapal kerja ini. Proses berikutnya adalah membuat pemodelan dari ukuran utama yang didapat, sehingga menghasilkan desain yang berupa gambar Rencana Garis (Lines Plan), Rencana Umum (General Arrangement) dan 3D Model.

\section{ANALISIS TEKNIS DAN PERHITUNGAN EKONOMIS}

\section{A. Analisis Teknis}

\section{1). Penentuan Payload}

Kapasitas angkut ditentukan dengan melihat volume jumlah sampah dan tumbuhan air yang ada di Sungai Kalimas Surabaya. Data lapangan mengenai kondisi sampah dan tumbuhan air khususnya eceng gondok tersaji pada Tabel 1 .

Tabel 1.

Jumlah Sampah dan Eceng Gondok yang Harus Diangkut

\begin{tabular}{ccc}
\hline \hline Item & Value & Unit \\
\hline Luasan cover area & 120.000 & $\mathrm{~m}^{2}$ \\
Lebar loading conveyor direncanakan & 2 & $\mathrm{~m}$ \\
Kecepatan saat beroperasi & 4 & $\mathrm{knot}$ \\
Waktu yang dibutuhkan untuk membersihkan & 8 & $\mathrm{jam}$ \\
Jumlah muatan total & 1.294 & $\mathrm{~m}^{3 /}$ tahun \\
Jumlah muatan total & 5.5 & $\mathrm{~m}^{3} / \mathrm{hari}$ \\
Ruang muat ditentukan & 6 & $\mathrm{~m}^{3}$ \\
Payload & 4 & ton \\
\hline \hline
\end{tabular}

Sumber: Perum Jasa Tirta I Kota Surabaya
6). Perhitungan Freeboard, Trim, dan Stabilitas

Untuk perhitungan Freeboard, Trim, dan Stabilitas, digunakan standar-standar yang berlaku sesuai yang diisyaratakan, Untuk perhitungan Freeboard, standar yang digunakan adalah Freeboard (NCVS) Indonesian Flagged Chapter 6 Section 5.1.2 [6]. Freeboard adalah selisih antara tinggi kapal dengan sarat kapal, dimana untuk tinggi kapal mencakup tebal kulit dan lapisan kayu jika ada, sedangkan T diukur pada sarat musim panas. Dengan Batasan bahwa $\mathrm{F}_{\mathrm{ba}} \geq$ $\mathrm{F}_{\mathrm{b}}$ ', sedangkan Trim adalah gerakan kapal yang mengakibatkan tidak terjadinya even keel. Trim terjadi akibat dari tidak meratanya momen statis dari penyebaran gaya berat. Trim dikatakan diterima apabila memiliki selisish antara LCG dengan LCB kurang dari 0,5\% $\mathrm{L}_{\mathrm{wl}}$, (SOLAS Chapter II-1, Part $B-1$, Regulasi 5-1) [7]. Sedangkan Stabilitas merupakan kemampuan kapal untuk kembali ke posisi atau kedudukan setimbang dalam kondisi air tenang ketika kapal mengalami gangguan dikarenakan adanya gaya tertentu. Untuk mengetahui bagaimana kemampuan kapal kembali pada kedudukan semula pada saat mengalami oleng, digunakanlah perhitungan stabilitas. Kriteria yang digunakan untuk perhitungan stabilitas adalah Marine Guide Notices (MGN) 280 Chapter 11 Section 3.7 [8].

Pada Tabel 4 dan Tabel 5 merupakan rekapitulasi perhitungan Freeboard, Trim dan Stabilitas:

Tabel 4 .

Rekapitulasi Perhitungan Freeboard dan Trim

\begin{tabular}{llccc}
\hline \hline No & \multicolumn{1}{c}{ Komponen Berat Kapal } & Value & Kriteria & Status \\
\hline \multirow{2}{*}{1} & Freeboard (NCVS) Indonesian & $1.03 \mathrm{~m}$ & $0.29 \mathrm{~m}$ & OK \\
& Flagged Chapter 6 Section 5.1.2. & $0.02 \mathrm{~m}$ & $0.046 \mathrm{~m}$ & OK \\
& Trim Kondisi A & $0.005 \mathrm{~m}$ & $0.046 \mathrm{~m}$ & OK \\
& Trim Kondisi B & $0.009 \mathrm{~m}$ & $0.046 \mathrm{~m}$ & OK \\
& Trim Kondisi C & $0.023 \mathrm{~m}$ & $0.046 \mathrm{~m}$ & OK \\
& Trim Kondisi D & $0.038 \mathrm{~m}$ & $0.046 \mathrm{~m}$ & OK \\
\hline
\end{tabular}

Tabel 5.

Rekapitulasi Perhitungan Stabilitas

\begin{tabular}{cccccc}
\hline \hline Kriteria: & \multicolumn{5}{c}{ Kondisi } \\
\cline { 2 - 6 } $\begin{array}{c}\text { Marine Guide Notices } \\
(M G N) \text { 280 Chapter 11 }\end{array}$ & $\mathrm{A}$ & $\mathrm{B}$ & $\mathrm{C}$ & $\mathrm{D}$ & $\mathrm{E}$ \\
Section 3.7 & & & & & \\
\hline $\mathrm{A} \theta \mathrm{max} \geq 0,075(\mathrm{~m} . \mathrm{rad})$ & 0.449 & 0.432 & 0.417 & 0.399 & 0.382 \\
$\mathrm{~A} \theta(30-40) \geq 0,03(\mathrm{~m} . \mathrm{rad})$ & 0.253 & 0.251 & 0.248 & 0.246 & 0.244 \\
GZ $\theta 30 \geq 0,2(\mathrm{~m} . \mathrm{rad})$ & 1.575 & 1.563 & 1.554 & 1.548 & 1.541 \\
$\theta \mathrm{GZmax} \geq 15^{\circ}$ & $17^{\circ}$ & $17^{\circ}$ & $17^{\circ}$ & $19^{\circ}$ & $20^{\circ}$ \\
GM $\geq 3.5 \mathrm{~m}$ & $8.916 \mathrm{~m}$ & $8.282 \mathrm{~m}$ & $7.718 \mathrm{~m}$ & $7.221 \mathrm{~m}$ & $6.778 \mathrm{~m}$ \\
Status & $\mathrm{OK}$ & $\mathrm{OK}$ & $\mathrm{OK}$ & $\mathrm{OK}$ & $\mathrm{OK}$ \\
\hline \hline
\end{tabular}

7). Rencana Garis dan Rencana Umum

Rencana Garis adalah gambar proyeksi badan kapal yang dipotong secara melintang (body plan), secara memanjang (sheer plan), dan vetikal memanjang (half breadth plan). Sedangkan Rencana Umum adalah perencanaan ruangan pada kapal, yang disesuaikan dengan fungsi, kebutuhan dan perlengkapan kapal [9]. Rencana Garis dan Rencana Umum dari kapal kerja ini dapat dilihat pada Gambar 4 dan Gambar 5. 

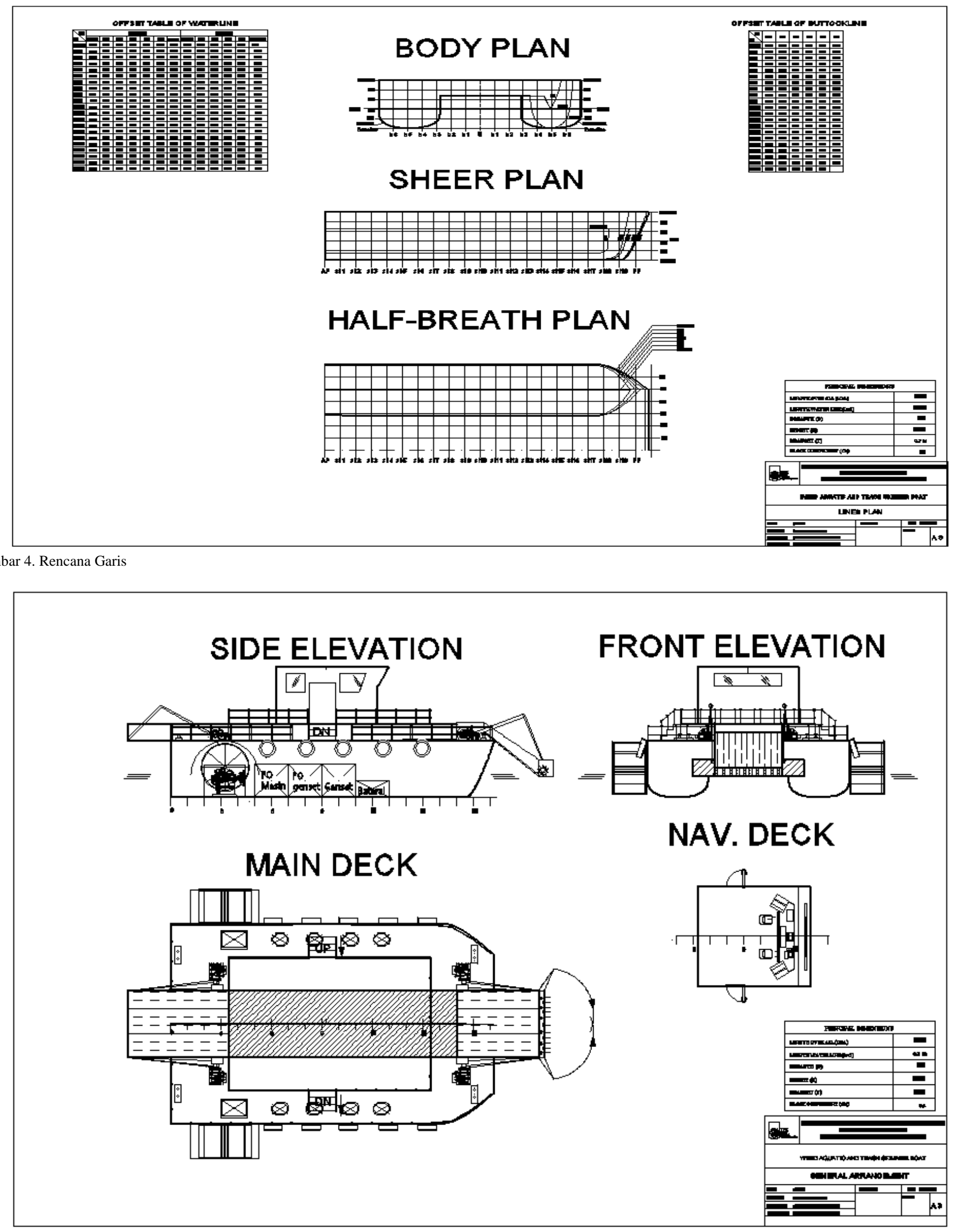


\section{9). Desain 3D Model}

Dari hasil desain rencana umum yang sudah dibuat, maka dilanjutkan dengan pembuatan 3D Model. Untuk 3D Model berturut-turut dapat dilihat pada Gambar 6 dan Gambar 7:

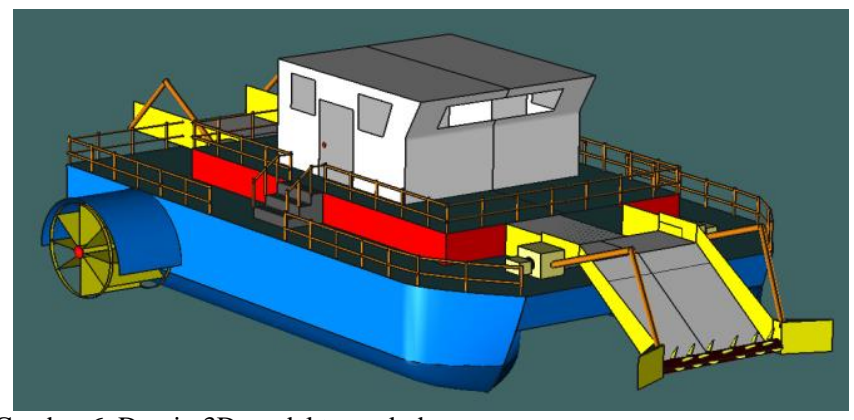

Gambar 6. Desain 3D model tampak depan.

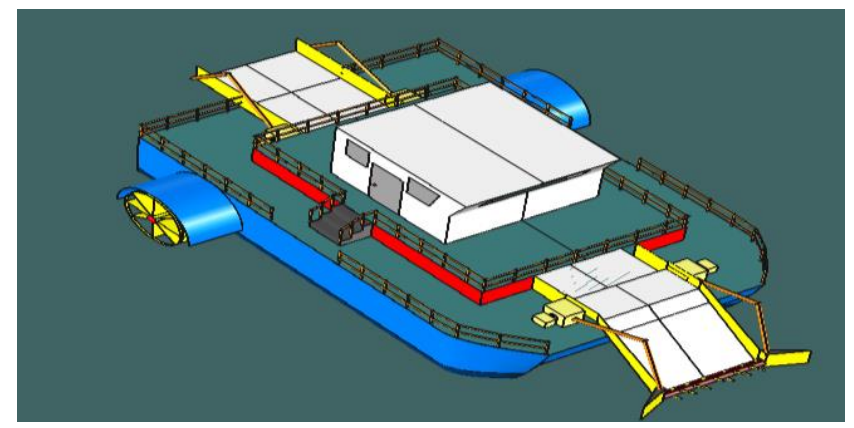

Gambar 7. Desain 3D model tampak atas.

\section{A. Perhitungan Ekonomis}

Biaya pembangunan kapal pada umumnya didominasi oleh biaya dari berat baja, dan biaya peralatan serta perlengkapan kapal serta biaya koreksi keadaan ekonomi dan kebijakan pemerintah [10].

Tabel 6.

Rekapitulasi Perhitungan Ekonomis

\begin{tabular}{lc}
\multicolumn{1}{c}{ Item } & Nilai \\
\hline \hline Baja Kapal \& Elektroda & 12.146 USD \\
Permesinan & 39.626 USD \\
Peralatan \& Perlengkapan & 5.709 USD \\
Total Harga & 57481 USD \\
Kurs Rp (per 1 Mei 2018, BI) & Rp.14.100,- \\
Biaya Pembangunan Total & Rp.1.134.670.088,- \\
\hline \hline
\end{tabular}

Pada Tabel 6 nilai tukar berdasarkan yang diterbitkan Bank Indonesia pada bulan Mei 2018 sebesar Rp.14.100 Selanjutnya Biaya Pembangunan dapat ditentukan dengan rumus Biaya Pembangunan Awal+Jasa Pembangunan+Biaya Inflasi + Biaya Pajak Pemerintah. Dengan demikian biaya pembangunan kapal kerja ini adalah Rp.1.134.670.088, -.

\section{KESIMPULAN}

Setelah melalui berbagai tahapan desain dan juga analisis teknis beserta perhitungan ekonomisnya, maka dari studi ini bisa ditarik beberapa kesimpulan sebagai berikut:
1. Berdasarkan data jumlah sampah dan tumbuhan air yang diperoleh dari Perum Jasa Tirta I Surabaya dapat ditentukan volume sampah dan tumbuhan air yang dapat diangkut oleh kapal setiap beroperasi sebesar 4 ton.

2. Didapatkan Ukuran Utama (Linesplan \& General Arrangement) yang optimum yaitu dengan sebesar $\mathrm{L}_{\mathrm{oa}}=9.6 \mathrm{~m}$, $\mathrm{L}_{\mathrm{wl}}=9,2 \mathrm{~m}, \mathrm{~B}=6 \mathrm{~m}, \mathrm{~B}_{\mathrm{oa}}=8 \mathrm{~m}, \mathrm{~B}_{1}=1.3 \mathrm{~m} \mathrm{~T}=0.7 \mathrm{~m}, \mathrm{H}=1.7$ $\mathrm{m}, \mathrm{C}_{\mathrm{b}}=0,5$ dan $\mathrm{V}_{\mathrm{S}}=4$ knots yang sesuai dengan karakteristik kebutuhan Sungai Kalimas Surabaya

3. Berdasarkan analisis teknis yang telah dilakukan diperoleh hasil sebagai berikut:

a) Berat kapal diperoleh; LWT sebesar 14.890 ton, dan DWT sebesar 4.264 ton, serta memiliki dispalsemen sebesar 19.32 ton.

b)Syarat minimum freeboard sebesar $0.297 \mathrm{~m}$ dan hasil perhitungan freeboard yang direncanakan sebesar $1.03 \mathrm{~m}$.

c) Hasil perhitungan Trim dan Stabilitas dikatakan memenuhi dari standar yang diisyaratkan yaitu $\leq 0.5 \% \mathrm{~L}_{\mathrm{wl}}$.

4. Pada saat membuat Lines Plan dan General Arrangement, kapal kerja ini didesain menggunakan paddle wheel untuk sistem penggeraknya karena sangat cocok dengan karakteristik Sungai Kalimas yang dangkal dan relatif sempit, sehingga diharapkan kapal ini dapat bekerja secara optimal dan efisien.

5. Desain kapal kerja yang memiliki konfigurasi lambung catamran ini dilengkapi tiga buah conveyor belt yang terdiri dari Loading Conveyor, Storage Conveyor, dan Offloading Conveyor, serta dilengkapi alat pemotong (cutter) yang terletak di depan Loading Conveyor. Rancangan ini merupakan desain yang cocok untuk karakter sampah dan tumbuhan air yang ada di Sungai Kalimas Surabaya.

6. Berdasarkan hasil perhitungan ekonomis, kapal kerja yang direncanakan ini dapat dibangun dengan biaya pembangunan sebesar Rp.1.134.670.088,-- per unitnya,

\section{DAFTAR PUSTAKA}

[1]
R. Hastijanti, "Permasalahan dan Solusi Pelestarian Kawasan Kota Lama Kalimas," in Seminar Pelestarian Kawasan Kota Lama, 2010, pp. 1-5.

A. G. Pramoko, "Studi Perancangan Trash-Skimmer Boat di Perairan Teluk Jakarta," ITS, 2013.

A. F. Insel, M. \& Molland, An Investigation Into The Resistance Components of High Speed Displacement Catamarans. London: RINA, 1992.

A. Primaningtyas, "Desain Kapal Wisata Sungai Dengan Penggerak Paddle Wheel Untuk Sungai Jagir Surabaya,” Surabaya, 2015.

N. Adiba, "Desain Trash Skimmer Amphibi-Boat Di Sungai Ciliwung Jakarta," 2016.

Anonymous, "Indonesian Flagged (NCVS) Chapter 6 Section 5.1.2."

Anonymous, "SOLAS Chapter II-1, Part B-1, Regulasi 5-1."

Anonymous, "Marine Guide Notices (MGN) 280 Chapter 11 Section 3.7."

D. Watson, "Practical Ship Design," Elsevier, vol. 1, 19998.

S. Adjie, "Evaluasi Teknis Sistem Propulsi Motor Sailing Boat Maryta Jaya 900," Surabaya, 1995. 